\title{
A Comparative Study of Nutritional Status of Economically Independent and Economically Dependent Urban Women in Lucknow City
}

\author{
Monika Agarwal $^{1 *}$, Chhavi Pant ${ }^{2}$, J. V. Singh ${ }^{3}$ \\ ${ }^{1}$ Associate Professor*, Department of Community Medicine and Public Health, KG Medical University, UP, Lucknow, Uttar Pradesh, India \\ ${ }^{2}$ Department of Community Medicine and Public Health, KG Medical University, UP, Lucknow, Uttar Pradesh, India \\ ${ }^{3}$ Professor, Department of Community Medicine and Public Health, KG Medical University, UP, Lucknow, Uttar Pradesh, India
}

\begin{abstract}
Background: Poor health of Indian women is of great concern to policy makers and program managers. It is generally expected that women who work at regular job, who earn money and contributes a substantial amount to the family earnings would likely to be more empowered than non-employed women. Their health and nutrition status would be in much better condition in comparison to the economically dependent women. Objectives: To compare the nutritional status and nutrients intake of economically independent and dependent women and effect of employment status of women on their nutritional status in relation to the underlying variables. Methods: Cross sectional study was conducted among 200 economically dependent and 200 economically independent women in urban areas of Lucknow city. Nutritional status of the study participants was assessed by anthropometric measurements, hemoglobin estimation and assessment of dietary intake. Discreet data was analyzed using Pearson's Chi square test for non formal distribution. Continuous data was analyzed using Wilcoxon (Mann Whitney) test and Student's test. P value $<0.05$ was considered significant in the study. Results: No significant difference in mean height, weight and BMI was found between economically dependent and economically independent women. Mean haemoglobin level was significantly higher in economically dependent women. On regression analysis, significant increase in nutrient intake was observed when we moved from the employed to the non-employed women group. Increase in education level was found to be associated with increase in intake of calories and proteins but not with the iron intake. Conclusions: Providing only the employment opportunities to the women is not sufficient to bring change in their nutritional status. With it, increase in their education level and raising their awareness about balanced diet and nutritional requirement is also very important.
\end{abstract}

Keywords: Economically dependent women, economically independent women, nutritional status, urban areas

\section{Background}

Malnutrition is a major public health problem in developing world. Poor health of the Indian women is of a great concern both at the national as well as at the individual level. In recent years there has been a remarkable upsurge of interest in the health, nutrition and fertility behavior of women in India. Post independence, there have been some impressive gains with respect to women's health. Life expectancy at birth for female, which stood at 31.7 in 1950, rose to 61.8 in 1997 and in currently it is $68.2^{\mathbf{1}}$. There has been decline in female infant mortality as well as female child mortality. But while more women are thus surviving, there is unfortunately not much evidence of substantial improvement in the nutritional status of the survivors.

Different nutritional surveys have highlighted high rate of inadequacies in nutritional status among females compared to the males in India. One important determinant of the nutritional status of women is the status of women in a society ${ }^{2}$. Women in India, have generally a 'lower status' than men in the society. Women lower status, challenges the decision making autonomy on the desired family size, health seeking behavior and the amounts and type of food fed to themselves and children ${ }^{3.4}$.

The Indian constitution grants women equal rights with men and makes special provisions for women to help them improve their status in society, but strong patriarchal tradition still persists in the Indian society which confined women with an oppressive environment. It is hypothesized that the well being of women in all aspects of their life is strongly connected to their economic status. Women who work at a regular job, who earn money are more likely to be empowered than the economically dependent women. They will have a greater degree of power and economic privilege. Most likely to be affected by employment is her health, in particular her nutrition and fertility. National Population Policy (2000) of India explicitly recognizes the importance of women's paid employment in achieving the goal of population stabilization and also specifies measures that will encourage paid employment and selfemployment of women. Various measures have been taken by government to improve the women's health and nutrition status. These measures include welfare and support services, training for employment and income generation, awareness generation and gender sensitization.

Most of the currently available studies ${ }^{5,6,7,8}$ on working women's, focused most of their attention mainly on impact of their employment or economic independence on the health of working women's children, decline in duration of breast feeding, fertility trends and contraceptive use etc. Very few researchers studied the effect of economic dependence of the woman on her nutritional status itself. Thus the present study was conducted to compare the nutritional status and nutrients intake of the economically independent and dependent women and to assess the effect of employment status of the women on nutritional status in relation to the underlying variables. 


\section{Materials and Methods}

Study Area: Present cross sectional study was conducted in urban areas of Lucknow district. Lucknow is the capital city of state of Uttar Pradesh.

Study Population: Economically independent and economically dependent married women of the reproductive age group residing in urban areas of Lucknow district.

Sample size: The sample size was estimated by taking into consideration the prevalence of under nutrition (BMI < $18.5 \mathrm{~kg} / \mathrm{m}^{2}$ ), 36\% (NFHS-2, India) ${ }^{9}$ and permissible level of error of 0.10 at $95 \%$ confidence interval. Since the national level data for the two groups were not separately available and prime objective of the study was to ascertain the difference in the nutritional status of economically independent and dependent women and, we took equal level of prevalence of under-nutrition in the two groups, to gain the maximum sample size. The sample size was calculated using the formula: $n=2 p(1-p) F / D^{2}$. A sample size of 177 women was required for each group; however the researchers increased the sample size to 200 in each group to make up for drop outs.

Sampling method: Four hundred women were included in the cross section survey. To get the representation of all the strata of the society in the study, the Lucknow city was divided into two parts taking into account the Gomati River as a geographical divide; Cis- Gomti representing the old city and Trans- Gomti which represents the modern part of the city. Thereafter from each part of the city two wards were randomly selected by getting the list of wards from the office of Municipal Corporation. In each ward, there are approximately 12-15 mohallas. Ten mohallas were randomly selected from these mohallas and from each mohallas approximately ten economically independent women were selected by using the snowballing technique and from the same neighborhood one economically dependent woman were selected for participation in the study. Thus hundred economically independent and 100 economically dependent women were selected from each ward.

Economically independent women is defined as, a woman currently working, either at home or outside in a craft or trade which fetches income in addition to performing the regular household work.

Women who were pregnant or lactating ( for $\leq$ six months) at the time of survey were not included in the study, because of impact of these physiological conditions on the maternal weight and changes in diet intake.

Data Collection: Quantitative data collection methods were used by researchers for gathering Information regarding type of locality, family characteristics, women's demographics characteristics, type of occupation, measurement of food/ nutrient intake, anthropometry assessment, clinical examination for overt signs for malnutrition and assessment of activity patterns. Updated Gupta and Mahajan's Socio economic classification was used to elicit the socioeconomic status of the family of the women $^{10}$.

\section{Assessment of Nutritional Status}

Nutritional status of the women was estimated by anthropometric assessment, hemoglobin estimation, clinical examination and assessment of dietary intake.

Dietary Intake: Dietary intake was assessed by $24 \mathrm{hr}$ recall oral questionnaire method. Standardized utensils were used; bowl was used to estimate the quantities of eaten cooked Dal, rice, vegetables,. Cups and glasses for measuring intake of tea, milk, coffee etc. and standardized spoons were used for measuring sugar, oil etc. Nutritive estimates were done utilizing nutritive value of Indian food for proximate principles and vitamin content per hundred grams of food items ${ }^{\mathbf{1 1}}$. The intake of nutrients by the study participants was compared with ICMR standards for recommended daily allowance RDA ${ }^{12}$.

\section{Anthropometric Assessment}

Weight: For all study subject's weight was recorded by using the bathroom scale. The weighing machine was checked for zero error before taking the weigh each time. The study subjects were weighed in minimum clothing with no foot wear. Weight was measured to the nearest 100 gms.

Height: The height was measured in the standing position on the level ground with a measuring tape. Subjects were made to stand straight with their head, shoulders, buttocks and heel vertically aligned against the wall. A hard board was put vertical to wall just above the head and height marked on the wall and measured to the nearest millimeter. The body mass index (BMI) was calculated using the formula: $\mathrm{BMI}=\mathrm{wt}(\mathrm{kg}) /$ height $^{2}(\mathrm{~m})$.

Hemoglobin estimation: Hemoglobin was estimated by using the acid hematin (Sahli's) method.

Clinical Examination: Study subjects were examined for the overt signs of nutrition deficiencies, viz; vitamin A, B, $\mathrm{C}$, D deficiency, anemia and iodine deficiency disorders.

Control over household income expenditure was asked by putting question, how much of the total income of the household is spent at your will, is it less than twenty five rupees in hundred earned (no autonomy) or about fifty (partial autonomy) or more than seventy five rupees (full autonomy).

Statistical Analysis: Data was analyzed using the software intercooled Stata version-8 for windows. Discreet data was analyzed using Pearson's Chi square test for non formal distribution. Continuous data was analyzed using Wilcoxon (Mann Whitney) test and Student's test. P value $<0.05$ was considered significant in the study. 


\section{International Journal of Science and Research (IJSR) ISSN (Online): 2319-7064 \\ Index Copernicus Value (2013): 6.14 | Impact Factor (2015): 6.391}

\section{Results}

Table 1: Biosocial characteristics of the Study subjects ( $N=400)$

\begin{tabular}{|c|c|c|c|}
\hline Biosocial Characteristics & $\begin{array}{l}\text { Economically Independent } \\
\qquad N=200\end{array}$ & $\begin{array}{l}\text { Economically dependent } \\
N=200\end{array}$ & $P$ value \\
\hline Mean current age (years) & $35.42+7.52$ & $34.30+8.45$ & 0.12 \\
\hline Mean age at marriage (years) & $20.81+5.45$ & $18.77+5.17$ & 0.0000 \\
\hline Mean number of children born & $2.41+1.87$ & $2.94+1.96$ & 0.005 \\
\hline Mean age at $1^{\text {st }}$ child birth (years) & $22.77+4.98$ & $20.69+3.03$ & 0.0001 \\
\hline Mean child loss & $0.13+0.47$ & $0.29+0.79$ & 0.003 \\
\hline Period of fertility* & $4.41+4.11$ & $9.06+6.12$ & 0.000 \\
\hline Mean family size (persons) & $5.24+2.6$ & $5.70+3.08$ & 0.034 \\
\hline \multicolumn{4}{|l|}{ Education of women } \\
\hline Illiterate & 16.50 & 30.50 & 0.000 \\
\hline Primary - Middle school complete & 18.50 & 16.50 & \\
\hline High school- intermediate complete & 10.00 & 28.00 & \\
\hline Graduate and above & 55.0 & 25.00 & \\
\hline \multicolumn{4}{|l|}{ Place of residence } \\
\hline Slum & 36.0 & 28.0 & 0.86 \\
\hline Non - Slum & 64.00 & 72.0 & \\
\hline \multicolumn{4}{|l|}{ Religion } \\
\hline Hindu & 86.00 & 84.0 & 0.479 \\
\hline Muslim & $14 . .50$ & 16.0 & \\
\hline \multicolumn{4}{|l|}{ Caste } \\
\hline SC/ST & 20.35 & 17.86 & 0.819 \\
\hline OBC & 19.77 & 21.43 & \\
\hline Others & 59.88 & 60.71 & \\
\hline \multicolumn{4}{|l|}{ Socio- economic status } \\
\hline Upper & 60.00 & 38.0 & 0.914 \\
\hline Middle & 27.50 & 41.50 & \\
\hline Lower & 12.50 & 20.50 & \\
\hline \multicolumn{4}{|l|}{ Type of family } \\
\hline Nuclear & 68.50 & 69.0 & 0.912 \\
\hline Joint & 31.50 & 31.0 & \\
\hline \multicolumn{4}{|l|}{$\begin{array}{l}\text { Autonomy of women over household } \\
\text { income expenditure }\end{array}$} \\
\hline Full autonomy & 49.50 & 16.00 & 0.000 \\
\hline Partially autonomy & 30.0 & 36.0 & \\
\hline No autonomy & 20.50 & 48.00 & \\
\hline
\end{tabular}

A total of 400 currently married, non- pregnant and nonlactating women of age group 15-49 years were interviewed. Most of women in the study were aged 25-48 years age group. There was no statistical significant difference between the current mean age of economically independent women and economically dependent women. No significant difference by religion, caste, place of residence was found between the economically independent women and economically dependent women groups. Majority $(60 \%)$ of the economically independent women was belonged to upper socio-economic class, but the two groups were not significantly different in socioeconomic status. There was significant difference between the education status of the two women groups and their husband's education status. In economically independent women group more than half of the women were educated up to graduate level or more. (Table 1).

The mean age of marriage and mean age at $1^{\text {st }}$ birth was significantly different lower in economically dependent women than the economically independent women $(20.81+5.45$ years). The two groups were significantly different in mean number of children born; mean family size and period of fertility.
Regarding decision making power over household income expenditure, economically independent women have significantly more power than the economically dependent women. Half of the economically independent women reported high decision making power than dependent women $(16.0 \%)$. Half of the economically dependent women reported low decision making power (Table 1).

Table 2: Employment characteristics of economically independent women and their contribution in total monthly household expenditure

\begin{tabular}{|l|c|}
\hline \multicolumn{1}{|c|}{ Employment characteristics } & $\%$ \\
\hline Occupation of women & \\
\hline Professional/Semiprofessional & 22.0 \\
\hline Clerk/ Shopkeeper & 32.0 \\
\hline Skilled/ Semi skilled worker & 19.0 \\
\hline Unskilled worker & 27.0 \\
\hline Type of service sector & 50.0 \\
\hline Public & 48.0 \\
\hline Private & 2.00 \\
\hline Self employed & \\
\hline $\begin{array}{l}\text { Woman Contribution in household } \\
\text { expenditure }\end{array}$ & 23.0 \\
\hline$<25 \%$ of household expenditure & 49.0 \\
\hline $25-50 \%$ of household expenditure & 12.50 \\
\hline $50-75 \%$ of household expenditure & 15.50 \\
\hline $75-100 \%$ of household expenditure & \\
\hline
\end{tabular}

\section{Volume 5 Issue 4, April 2016}




\section{International Journal of Science and Research (IJSR) \\ ISSN (Online): 2319-7064 \\ Index Copernicus Value (2013): 6.14 | Impact Factor (2015): 6.391}

About one fifth of the economically independent women were working as skilled and semi- skilled worker and one fourth were engaged as unskilled worker. Only $2.0 \%$ of the women were self employed. About half of the economically independent women were contributing 25\%$50 \%$ in total monthly household expenditure and fifteen percent were making more than $75 \%$ contribution in their monthly household expenditure (Table 2).

Table 3: Distribution of women by their type of physical activity, time division per day and food distribution in the family, $(\mathrm{N}=400)$

\begin{tabular}{|c|c|c|c|}
\hline & $\begin{array}{c}\text { Economically } \\
\text { Independent } \\
N=200\end{array}$ & $\begin{array}{c}\text { Economically } \\
\text { dependent } \\
N=200\end{array}$ & $\begin{array}{c}P \\
\text { value }\end{array}$ \\
\hline $\begin{array}{l}\text { Working hours } \\
\text { at work place }\end{array}$ & $8.13+1.42$ & - & \\
\hline $\begin{array}{l}\text { Working hours } \\
\text { at home }\end{array}$ & $6.84+2.28$ & $7.43+2.85$ & ns \\
\hline $\begin{array}{l}\text { Total working } \\
\text { hours }\end{array}$ & $14.95+2.54$ & $7.43+2.85$ & 0.000 \\
\hline $\begin{array}{l}\text { Hours of } \\
\text { sleeping } \\
+ \text { +relaxation } \\
\end{array}$ & $9.16+2.64$ & $17.47+4.19$ & 0.000 \\
\hline $\begin{array}{l}\text { Type of } \\
\text { physical } \\
\text { activity }\end{array}$ & (\%) & (\%) & \\
\hline Sedentary & 52.50 & 51.50 & 0.000 \\
\hline Moderate & 38.50 & 48.50 & \\
\hline Heavy & 09.0 & 0.00 & \\
\hline \multicolumn{4}{|l|}{$\begin{array}{l}\text { Order of } \\
\text { serving of food }\end{array}$} \\
\hline $\begin{array}{l}\text { Along with } \\
\text { husband and } \\
\text { children }\end{array}$ & 37.0 & 42.50 & 0.001 \\
\hline $\begin{array}{l}\text { After Husband } \\
\text { along with } \\
\text { children }\end{array}$ & 4.00 & 6.00 & \\
\hline $\begin{array}{l}\text { After husband } \\
\text { and children }\end{array}$ & 34.50 & 42.00 & \\
\hline $\begin{array}{l}\text { No fixed time } \\
\text { for food }\end{array}$ & 24.50 & 9.50 & \\
\hline
\end{tabular}

The activity patterns of the women are shown in Table 3. The economically independent women spent about eight hours at their working place. Both the groups reported almost equal working hours (07 hours) at home. Total working hours of economically independent women were significantly longer (14 hrs) than the economically dependent women. Hours spent on sleeping and relaxation was significantly lower (09hrs) in economically independent women than the economically dependent women group. Half of the women in both the groups were sedentary workers. About $10 \%$ of women in economically independent group were heavy workers. Almost same number of women in both the groups serves food to themselves either along with the husband and children or after husband and children. But in economically independent women one fourth of the women said they eat food whenever they have time.
Table 4: Health and Nutritional Status of the study subjects, $(\mathrm{N}=400)$

\begin{tabular}{|c|c|c|c|c|c|}
\hline & \multicolumn{2}{|c|}{$\begin{array}{c}\text { Economically } \\
\text { Independent } \\
N=200\end{array}$} & \multicolumn{2}{c|}{$\begin{array}{c}\text { Economically } \\
\text { Dependent } \\
N=200\end{array}$} & $\begin{array}{c}P \\
\text { value }\end{array}$ \\
& Mean & SD & Mean & SD & \\
\hline Height & 154.44 & 7.97 & 152.55 & 9.58 & $\mathrm{~ns}$ \\
\hline Weight & 53.23 & 11.26 & 54.73 & 10.37 & $\mathrm{~ns}$ \\
\hline BMI & & & & & \\
\hline$<18.5($ low) & 16.50 & & 10.50 & & $\mathrm{~ns}$ \\
\hline $\begin{array}{c}18.5-25 \\
\text { (normal) }\end{array}$ & 56.0 & & 60.00 & & \\
\hline$>25$ (high) & 27.0 & & 29.50 & & \\
\hline Mean + SD & 22.71 & 4.7 & 24.58 & 4.8 & $\mathrm{~ns}$ \\
\hline Hb gm\% & $\mathbf{N}=\mathbf{4 8}$ & & $\mathbf{N}=\mathbf{4 6}$ & & \\
\hline$<12$ gm\% & 25.00 & & 19.57 & & \\
\hline$>12$ gm\% & 75.0 & & 80.43 & & $\mathrm{~ns}$ \\
\hline Mean + SD & 10.13 & 1.13 & 10.76 & 1.32 & 0.03 \\
\hline
\end{tabular}

No significant difference was found between the mean height, weight and BMI of economically dependent and economically independent women (Table 4). In both the groups, about one fourth of the women were overweight (BMI $\left.>25 \mathrm{~kg} / \mathrm{m}^{2}\right)$.Hemoglobin estimation was done in the sub sample population (20\% of the total sample size) and the difference in the mean hemoglobin level was significantly higher in economically dependent women. On clinical examination signs and symptoms of anemia was observed in about half of the women of both the groups and angular stomatitis was visible in 11 and 15 economically independent and economically dependent women respectively. Low backache was reported more by employed women (45.50\%) in comparison of the economically dependent women (37\%).

Table 5: Dietary intake per day by the study subjects

\begin{tabular}{|c|c|c|c|c|c|}
\hline \multirow[t]{2}{*}{$\begin{array}{c}\text { Nutrients } \\
\text { intake } \\
\text { /day }\end{array}$} & \multicolumn{2}{|c|}{$\begin{array}{c}\text { Economically } \\
\text { Independent } \\
N=200(\%)\end{array}$} & \multicolumn{2}{|c|}{$\begin{array}{c}\text { Economically } \\
\text { Dependent } \\
N=200\end{array}$} & \multirow[t]{2}{*}{$\begin{array}{c}P \\
\text { valu } \\
e \\
\end{array}$} \\
\hline & Mean (SD) & $\begin{array}{c}\% \\
R D A\end{array}$ & Mean (SD) & $\begin{array}{c}\% \\
R D A\end{array}$ & \\
\hline $\begin{array}{c}\text { Calories } \\
\text { (Cal) }\end{array}$ & $\begin{array}{c}1912.22 \pm \\
575.8\end{array}$ & $\begin{array}{c}91.2 \\
4\end{array}$ & $2074.3+598.9$ & 98.2 & $\begin{array}{c}0.00 \\
1\end{array}$ \\
\hline $\begin{array}{l}\text { Proteins } \\
\text { (gm) }\end{array}$ & $\begin{array}{r}54.54 \\
\pm 19.75 \\
\end{array}$ & $\begin{array}{c}105 . \\
7\end{array}$ & $60.67 \pm 19.69$ & $\begin{array}{c}113 . \\
8\end{array}$ & $\begin{array}{c}0.00 \\
0\end{array}$ \\
\hline $\begin{array}{l}\text { Fats } \\
\text { (gms) }\end{array}$ & $29.75+15.44$ & $\begin{array}{c}142 . \\
7 \\
\end{array}$ & $29.13+16.20$ & $\begin{array}{c}145 . \\
6 \\
\end{array}$ & ns \\
\hline $\begin{array}{c}\text { Calcium } \\
\text { (mg) }\end{array}$ & $\begin{array}{c}853.05 \pm 46.3 \\
8 \\
\end{array}$ & $\begin{array}{c}201 . \\
8\end{array}$ & $889.87+42.32$ & $\begin{array}{c}196 . \\
5\end{array}$ & ns \\
\hline Iron (mg) & $22.97 \pm 13.76$ & 74.0 & $26.44+13.56$ & 86.0 & $\begin{array}{c}0.00 \\
0\end{array}$ \\
\hline $\begin{array}{l}\text { Vitamin } \\
\text { A (IU) }\end{array}$ & $\begin{array}{c}585.11+ \\
708.21 \\
\end{array}$ & 95.5 & $\begin{array}{c}582.42+579.3 \\
5 \\
\end{array}$ & 92.3 & ns \\
\hline $\begin{array}{c}\text { Thiamin } \\
\text { (mg) }\end{array}$ & $1.19+0.78$ & $\begin{array}{c}112 . \\
0\end{array}$ & $1.16 \pm 0.78$ & $\begin{array}{c}128 . \\
0\end{array}$ & ns \\
\hline $\begin{array}{c}\text { Riboflavi } \\
\text { n (mg) }\end{array}$ & $1.45+0.48$ & $\begin{array}{c}131 . \\
8\end{array}$ & $1.52 \pm 0.30$ & $\begin{array}{c}127 . \\
3\end{array}$ & ns \\
\hline $\begin{array}{c}\text { Niacin } \\
(\mu g)\end{array}$ & $13.60+4.89$ & $\begin{array}{c}101 . \\
7\end{array}$ & $17.04+12.17$ & 142 & $\begin{array}{c}0.00 \\
0\end{array}$ \\
\hline $\begin{array}{l}\text { Ascorbic } \\
\text { acid (mg) }\end{array}$ & $54.35 \pm 63.44$ & $\begin{array}{c}130 . \\
6\end{array}$ & $56.5 \pm 56.2$ & $\begin{array}{c}131 . \\
4\end{array}$ & ns \\
\hline
\end{tabular}

In both the groups, the mean intake of calories, less than the recommended daily allowance for the sedentary worker. Intake of calories was significantly lower $(p<0.05)$ in economically independent than the economically 


\section{International Journal of Science and Research (IJSR) \\ ISSN (Online): 2319-7064 \\ Index Copernicus Value (2013): 6.14 | Impact Factor (2015): 6.391}

dependent women. Mean intake of protein and iron was also significantly lower in economically independent women than economically dependent women. Women of both the groups were taking less iron in their diet in comparison to recommended daily allowance. Women of both the groups were consuming fats in higher amount than required.
Twelve percent of economically independent women and fifteen percent of the economically dependent women were taking some nutritional supplement at the time of survey. Intake of nutritional supplement was not significantly different between the two groups (Table 5).

Table 6: Regression Analysis of Daily Nutrient Intake in Relation to Bio Social Characteristics

\begin{tabular}{|c|c|c|c|c|c|c|}
\hline Biosocial characteristics & \multicolumn{2}{|c|}{ Calories intake } & \multicolumn{2}{|c|}{ Protein intake } & \multicolumn{2}{c|}{ Iron intake } \\
\hline & $\beta$ coefficient & $P$ value & $\beta$ coefficient & $P$ value & $\beta$ coefficient & $P$ value \\
\hline Employment status & 216.9 & $0.001^{*}$ & 8.7 & $0.000^{*}$ & 4.45 & $0.006^{*}$ \\
\hline Age of the women & 93.2 & $0.031^{*}$ & 3.8 & $0.011^{*}$ & 0.92 & 0.395 \\
\hline $\begin{array}{c}\text { Educational status of } \\
\text { women }\end{array}$ & 55.3 & $0.021^{*}$ & 2.0 & $0.014^{*}$ & -0.01 & 0.980 \\
\hline Type of residence & 274.0 & $0.002^{*}$ & 2.7 & 0.337 & 1.56 & 0.486 \\
\hline Family type & 163.7 & $0.006^{*}$ & 3.88 & 0.066 & 2.77 & 0.065 \\
\hline Socio-economic status & -91.18 & 0.952 & -1.01 & $0.014^{*}$ & -1.43 & 0.297 \\
\hline Religion & -94.7 & 0.221 & -3.91 & 0.153 & 2.18 & 0.262 \\
\hline Husband's education & -26.8 & 0.326 & -0.45 & 0.63 & 0.18 & 0.788 \\
\hline $\begin{array}{c}\text { Autonomy of women over } \\
\text { household income } \\
\text { expenditure }\end{array}$ & 15.7 & 0.669 & -0.23 & 0.861 & -0.79 & 0.393 \\
\hline
\end{tabular}

$* \mathrm{p}<0.05$

When taking into account age, educational status, employment status, type of residence, socioeconomic status, religion, husbands education and autonomy of women over household income expenditure, significant difference was found in daily intake of calories, proteins and iron of economically independent and economically dependent women (Table 6).

On regression analysis of nutrients intake (calories, protein, iron) in relation to working status of women, age, and educational status of self, husband's educational status, and type of family, place of residence, socioeconomic status and autonomy over the household expenditure.

Elder age women, educational status of women, not employed status of women, place of residence in non-slum locality and joint family of woman was found to be significantly associated with intake of calories, ( $\beta$ coefficient- 93.0, 55.34, 216.98, 274.06 respectively).

Not working status of women, elder age and high educational status was also found to be significantly associated with intake of proteins. Socioeconomic status was found to significantly negatively associate with the intake of protein.

Any of the biosocial factors except economic dependence was found not to be significantly associated with iron intake. Religion, Husband's education and autonomy of woman over the household expenditure lost their significance for any nutrient intake in the regression analysis.

\section{Discussion}

The present study was undertaken to adjudge whether joining the labor force makes a difference to the health and nutrition status of a woman. No significant difference in current mean age, religion, caste and socioeconomic status was found between economically dependent and economically independent women. Mean years of age at marriage and mean age at first birth was significantly high in economically independent women. In the study the employed women were significantly more educated as well as their husbands were also more educated than the not working women. More than half of the economically independent women were clerk or professionals and nineteen percent were skilled workers. No significant difference in working hours home was found between employed and non- employed woman. Similar to Khan et al findings working women were doubly burden and on an average spending 12-13 hours per day for various kinds of works.

In the present study, employed women were making significant contribution to the household expenditure. About $49.0 \%$ of the women were contributing up to 25$50 \%$ in their family expenditure and more than one fourth were contributing more than $50 \%$ of household expenditure; similar findings were also reported by other researchers ${ }^{13}$. A woman who brings in money is expected to exercise a greater control over the purse strings. In the study significantly more number of employed women (49.0\%) had high autonomy to take decision about household income expenditure in comparison to the not employed women (16\%). But twenty percent of women reported that they had no autonomy over household income expenditure. In NFHS-3 survey ${ }^{14}$ more than one quarter of the women who earn cash reported that only their husbands or others make decision about how the money they earn will be used.

No significant difference in height, weight, body mass index was found between economically dependent and economically independent women groups. Contrary to what hypothesized, employment status of the women was not found to be associated with her BMI status. Prevalence 


\section{International Journal of Science and Research (IJSR) \\ ISSN (Online): 2319-7064 \\ Index Copernicus Value (2013): 6.14 | Impact Factor (2015): 6.391}

of under nutrition $\left(\mathrm{BMI}<18.5 \mathrm{~kg} / \mathrm{m}^{2}\right)$ was found to be higher in economic independent women but it was not significantly different between the two groups. Mean hemoglobin level was also found to be significantly higher in the economically dependent women in comparison to working women. This corroborates with the findings that economically independent women were taking low iron in their diet in comparison to economically dependent women.

Among both the groups, high number of women was eating food after their husbands and children. This shows that preexisting social customs dominate largely in both the groups. But in this study about one fourth of the economically independent women said that their food time is not fixed; ending up taking food at odd hours or sometimes no food at all in a day. This approach towards food intake may have detrimental effect on the health and nutritional status of the women.

Except calories and iron, the women of both the groups in the study were consuming all the other nutrients adequately or on higher side of recommended daily allowance for sedentary worker. However, if the type of physical activity will be considered they will fall short of the requirement. In the study, about half of the women were moderate to heavy workers in both the groups. Both economically independent and economically dependent will fall short of the calorie requirement by $85.7 \%$ and $93.20 \%$ of the RDA for moderate worker respectively. Intake of the calories will be much less for the heavy worker recommended daily allowances, who were nine percent of the employed women. In comparison of economically dependent women there was significant lower intake of calories, proteins, iron and niacin by the economically independent group. The situation was much worse for iron intake; it was $74.0 \%$ of RDA in the economically independent women and $86.0 \%$ of RDA in economically dependent women respectively. Khan et $\mathrm{al}^{13}$ reported calorie intake of $67 \%$ of and $84 \%$ of RDA by the working and non working women. They also reported less intake of protein than the recommended daily allowance; $78.4 \%$ and $82.2 \%$ of RDA by the working and non working women respectively.

When daily intake of calories, proteins, calcium and iron of economically independent and dependent women were studied taking into account their biosocial correlates, it was found that significant difference exists for almost all the independent variables between the two groups. Economically independent women from younger age group (15-25yrs ), less educated, living in slum locality, Muslim and belonging to low socio economic class were consuming significantly fewer amounts of calories and proteins from their economically dependent counterparts.

On regression analysis, significant increase was found in the intake of the nutrients when we moved from the employed to non-employed group. Autonomy of woman over household expenditure had no significant effect on the nutrient intake by the women. Increase in level of educational status was found to be associated with an increase in intake of calories and protein. Thus it shows that providing the women with employment opportunity or her autonomy over the household expenditure is not sufficient to bring any change in their nutrients intake or health. Women participation in wage work alone do not provide them higher status in household, as husbands or other family members (mother in laws/father in laws) usually control all household income, including women income. Lado C. ${ }^{15}$ opined women spend their income on the family whereas men tend to spend theirs on themselves.

In addition to economic empowerment of the women, educating the women and increasing their awareness about their health needs, consumption of balanced diet, healthy life style will be more beneficial for their health and in turn will also positively affect the health of their family.

\section{Conclusion}

In sum, there are indications that women' work participation, their income and autonomy over the household income alone not guarantee the nutrient intake and health status. Women's employment along with education is the major mean to improve the nutrition and health. There is need to emphasize to increase her knowledge about the nutritional needs and balanced diet which will empower her to take better decision in favor of not only her nutrition and health but also for her family . In addition to this, it is essential to foster the concept among women of improving nutrition for their own health rather than for their family or children sake. Women especially from low socio economic classes, younger age group, and Muslim community who are also less educated should be made aware about their nutritional requirements, balanced diet etc. Even working women from this section of society are less educated and there is need to make them more aware about their nutritional needs. The more aware women will significantly have better nutrition knowledge, food habits, self concepts and better health.

There is also need to study the effects of varied occupations environment on the health and nutritional status of woman where she is working in Indian scenario.

\section{References}

[1] India- Life expectancy at birth. www.country economy.com/demographic/life- expectancy/India. Last accessed on 30/08/2015

[2] Haddad, Lawrence. (1999). Women's Status: Levels, Determinants, Consequences for Malnutrition, Interventions, and Policy. Asian Development Review, 17, (1, 2): 96-131, Asian Development Bank.

[3] Heaton, Tim B. and Forste, Renata (2007). Domestic Violence, Couple Interaction and Children's Health in Latin America. Springer Science + Business Media, LLC 2007, J Fam Viol (2008) 23:183-193

[4] SR Patrika, DR Basanna, Sharma S. (2014) .Women Empowerment and Use of Contraception. Medical Journal Armed Forces India, 70,253-256

[5] MA Kabir, MMH Khan, M Kabir, M Muzibir. Impact Of Woman's Status On Fertility And Contraceptive Use In Bangladesh: Evidence from Bangladesh 
Demographic and Health Survey,1999-2000, online source-www.researchgate.net/profile/M-

Kabir/Publication/234022907

[6] Abbi R, Christian P, Gujral S (1997).The Impact of Maternal Work Status on Nutrition and Health Status of Children. Online source-archive.unupress /food/8F131e/8F131EO3.htm.last accessed on $30 / 08 / 2015$

[7] Yeleswarapu BR,Nallapu SSR. (2012): A comparative study on the nutritional status of the preschool children of the employed women and the unemployed women in urban slums of Guntur. J Clin Diagn Res,6(10):1718-1721

[8] Tebekaro Y (2011): Women's decision making autonomy and their nutritional status in Ethiopia. Online source-paa 2011.princeton .edu/papers/110116, last accessed on 30/08/2015

[9] Text Book of Preventive and Social Medicine, K.Park Ed.17 (2002).

[10]B.K. Mahajan and M.C. Gupta. Text Book of Preventive and Social Medicine, Ed IInd (1995)

[11] Nutritive Value Of Indian Foods, Revised Edition (1989) C. Gopalan, B.V.Rama, S.C. Bala Subramanian. National Institute of Nutrition.

[12] ICMR (1998). Nutritive Requirements And Recommended Dietary Allowances For Indians

[13] Khan ME,Tamang AK,Patel Bella C. (1990).Work Pattern of women and its impact on Health and Nutrition: Some observations from the Urban Poor. Journal of Family Welfare, Vol 36 (2).3

[14] National Family Health Survey (NFHS-3): //http://mohfw.nic.in/nfhsfactsheet.html

[15] Lado C. female labour participation in agricultural production and the implications for nutrition and health in rural Africa. Social Science and medicine,1992,34(7);789-807 